\title{
脳卒中片麻痺者における立ち上がり動作と座位での 下肢荷重力との関連
}

\section{Relationship between the Ability of Sit-to-Stand Movement and Lower Limb Loading Force in Sitting Position of Hemiplegics Patients}

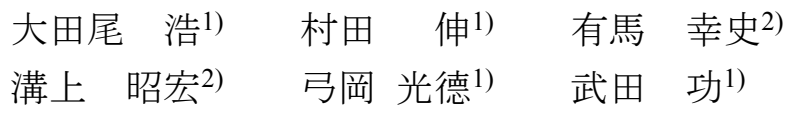

HIROSHI OTAO, RPT ${ }^{1)}$, Shin MURATA, RPT ${ }^{1)}$, KoJI ARIMA, RPT ${ }^{2)}$, AKIHIRO MIZOKAMI, RPT ${ }^{2)}$, MITSUNORI YUMIOKA, RPT ${ }^{1)}$, ISAO TAKEDA, RPT ${ }^{1)}$

1) Department of Physical Therapy, Faculty of Health Care Sciences, Himeji Dokkyo University: 7-2-1 Kami Ohno, Himeji City, Hyogo 670-8524, Japan. TEL +81 79-223-2211

2) Department of Rehabilitation, Kahan Hopsital

Rigakuryoho Kagaku 22(2): 293-296, 2007. Submitted Nov. 10, 2006. Accepted Jan. 23, 2007.

\begin{abstract}
We measured lower limb loading force of hemiplegics patients with a commercially available scale and studied the relationship with sit-to-stand movement ability. The subjects, 40 hemiplegics patients (17 men and 23 women, mean age 72.7) were divided into 3 groups, need care for sit-to-stand, self-supporter with condition (need upper limb support) and self-supporter, and compared each group with lower limb loading force. The total value of lower limb loading force of the non-paralyzed and paralyzed sides showed significant differences in sit-to-stand ability. The more independent at sit-to-stand the patients were, the bigger the value of lower limb loading force was. This knowledge suggests that the measurement of lower limb loading force in the sitting position is useful for a simple lower limb function assessment reflecting sit-to-stand movement. Especially, since this method is possible in the sitting position, it can be used for hemiplegic patients whose treatment does not allow sit-to-stand movement to predict the prognosis of sit-to-stand movement.
\end{abstract}

Key words: lower limb loading force, sit-to-stand movement, hemiplegic patients

要旨：本研究は，脳卒中片麻痺者を対象に市販体重計を用いて下肢荷重力を測定し，立ち上がり動作能力との関連に ついて検討した。対象は, 脳卒中片麻盘者40名（男性17名, 女性23名, 平均年齢72.7歳) で, 立ち上がり要介助群, 条 件付き（要上肢支持）自立群, 自立群の3つに分類し, それぞれの下肢荷重力を比較した。その結果, 非麻痺側と麻痺 側の下肢荷重力の合計值は，立ち上がり動作能力別に有意差が認められ，立ち上がりが自立している者ほじ大きな下 肢荷重力測定值を示した。これらの知見から，座位での下肢荷重力測定は，立ち上がり動作を反映する簡易下肢機能 評価法として有用であることが示唆された。とくに, 坐位で測定が可能なため, 治療上立ち上がり動作が許可されて いない片麻痺者の立ち上がり動作の予後予測に使用できる可能性が示唆された。

キーワード：下肢荷重力，立ち上がり動作，脳卒中片麻痺者

1）姫路獨協大学＼cjkstart医療保健学部理学療法学科：兵庫県姫路市上大野7-2-1（广670-8524）TEL 079-223-2211

2) 河畔病院 リハビリテーション科

受付日 2006年11月10日＼cjkstart受理日２007年1月23日 


\section{I. 緒 言}

一般に脳卒中片麻痺者の評価で使用される評価法は Brunnstrom Stage ${ }^{1)}$ (以下Br.ステージ) や上田らの12段階 片麻痺回復グレード法2), Motricity Index ${ }^{3)}$ などがある。 しかし, 実際に用いると判定基準の不明確さや検者間に おける判定の相違などを経験する。また, 患者によって は回復の過程において機能的な変化が認められても, 評 価結果に反映されないことも多い。

一方, 下肢機能の評価は10 m歩行速度や片脚立位保持 時間の測定など，動作能力の評価が多く行われている。 なかには，等速性筋力測定機器4-6)を用いた筋力評価や, 重心動摇解析装置7-8)を用いたバランス評価などが行わ れているが, それらの測定機器は高価なものが多く, 臨 床現場での使用は限られる。

そこで, 筆者らは使用場所を選ばない, 市販体重計を 用いた簡易下肢機能評価法として座位での下肢荷重力 測定法を考案し, その測定法の信頼性と妥当性を検討し てきた 9,10$) 。$ 本研究では, 脳卒中片麻痺者にとって重要 な基本動作の一つである, 立ち上がり能力と座位での下 肢荷重力との関連について検討した。

\section{II. 対象と方法}

\section{1. 対象}

対象は，某通所リハビリテーション施設に通所して いる片麻痺者のうち, 重度の認知症と失語症が認められ ない40名（男性17名 女性23名）を対象とした。対象者 の属性は平均年齢72.7 19.9 歳（45歳～91歳）であり, 疾 患名は脳梗塞が29名 $(72.5 \%)$ と多く, 発症からの期間 は平均 $58.2 \pm 43.9$ ケ $(8$ ケ〜 142 ケ)を経過していた。 下肢の麻痺の程度についてはBr.ステージIIIが21名 (52.5 \%) と最も多かった。なお，対象者のすべてにおいて， 測定に支障を来たすほどの知的障害はなかった（表1）。

対象者の立ち上がり動作能力は立ち上がり自立群が 12名 $(30 \%)$ ，上肢の支持などが必要な条件付き自立群 が17名 $(42.5 \%)$ ，自力で立ち上がれない立ち上がり要 介助群が 11 名 $(27.5 \%)$ であった。

\section{2. 測定方法}

1）下肢荷重力の測定方法

測定姿位は，治療台（プラットホーム型 : 高さ45 cm) に端座位をとり, 足底に体重計を置いた状態で治療台端 と膝窩部間を拳1個分空ける（図1-A）。測定開始の合図
表 1 対象者の属性

\begin{tabular}{lll}
\hline 人数 (名) & 40 (男性 17, 女性 23) & \\
年齢 (歳) & $72.7 \pm 9.9(45-91)$ & \\
平均体重 $(\mathrm{kg})$ & $52.5 \pm 9.0(37-70)$ & \\
疾患名 (人数) & 脳梗塞 29, 脳出血 & 11 \\
発症からの期間 (月数) & $58.2 \pm 43.9(8-142)$ & \\
麻痺側 (人数) & 右 21 , 左 19 & \\
\hline Br. ステージ(人数) & I & 1 \\
& II & 5 \\
& III & 21 \\
& IV & 6 \\
& V & 7 \\
& VI & 0 \\
\hline 立ち上がり & 自立群 & 12 \\
& 条件付き自立群 & 17 \\
& 立ち上がり要介助群 & 11 \\
\hline
\end{tabular}

平均土標準偏差

とともに，下肢で体重計を垂直方向に最大努力下で3秒 間押してもらった。その際，体幹の矢状面および前額面 での動きは制限せず, 体重計を押しやすい姿勢をとらせ たが，臀部を治療台から離さないように留意した（図1B）。測定は非麻痺側および麻痺側につき2回ずつ行い, その最大值を下肢荷重力 $(\mathrm{kg})$ とした。下肢荷重力は非 麻痺側, 麻痺側, 両側の合計について, 体重比百分率 （\%) に換算して分析した。

2）立ち上がりの評価方法

立ち上がりの評価は，裸足にて高さ $45 \mathrm{~cm}$ の治療台端 坐位から開始した。口頭指示「立ち上がって下さい。」 を合図に動作を開始したが，その際，上肢で膝や治療台 を押して立ち上がった場合は, 再度上肢を使用しないで 立ち上がれるか否かを確認した。本研究では立ち上がり 方法について以下の3つに分類した。上肢の支持を使用 せず立ち上がれる群を自立群, 上肢で座面を押すことで 立ち上がれる群を条件付き自立群, 介助がないと立ち上 がれない群を要介助群とした。なお，立ち上がり後の立 位姿勢が安定したのを確認して動作終了とした。

\section{3. 統計処理}

統計学的処理は立ち上がり能力別に分けた3群間の下 肢荷重力を一元配置分散分析で比較し, 多重比較検定に はScheffe法を用いて検討した。 


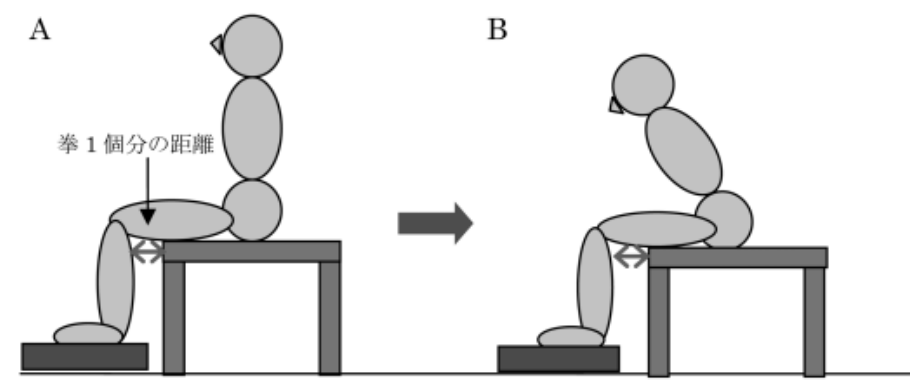

体重計

図1 開始姿位・測定姿位

A : 端座位姿勢をとり座面端と膝窩間には拳 1 個分空ける.

B : 反動をつけず, ゆっくり3秒間押す。その際，慰部を座面から離さない

ようにする。

表 2 下肢荷重力と立ち上がり能力別群との比較

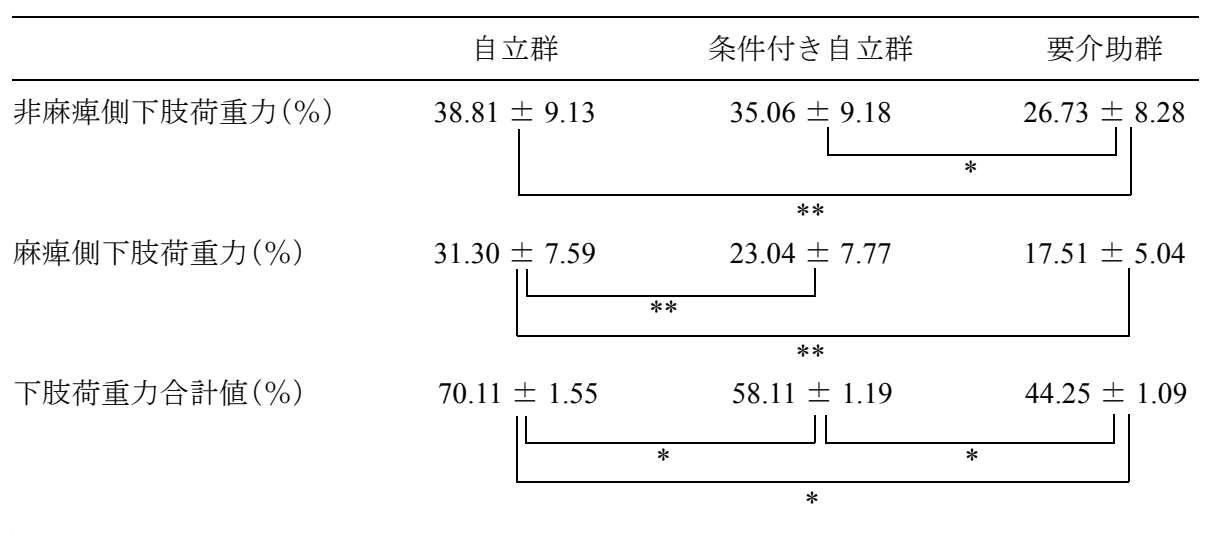

平均土標準偏差, ${ }^{*} \mathrm{p}<0.05, \quad * * \mathrm{p}<0.01$

4. 倫理的配慮

対象者には, 研究の趣旨と内容について説明し, 理解 を得た上で協力を求めたが, 研究の参加は自由意志であ り, 被検者にならなくても不利益にならないことを十分 に説明した。なお，データはコンピューターで処理し， 研究の目的以外には使用しないこと及び個人情報の漏 洩に注意した。

\section{III. 結 果}

\section{1. 非麻痺側下肢荷重力の比較}

非麻痺側下肢荷重力において，要介助群と条件付き 自立群の間で有意差が認められた $(\mathrm{p}<0.05)$ 。また, 要 介助群と自立群の間でも有意差が認められた $(\mathrm{p}<0.01)$ 。 条件付き自立群と自立群の間には有意差は認められな
かった（表2）。

\section{2. 麻痺側下肢荷重力の比較}

麻痺側下肢荷重力においては, 要介助群と自立群の 間で有意差が認められた $(\mathrm{p}<0.01)$ 。また, 条件付き自 立群と自立群間にも有意差が認められた（ $<0.01 ） 。$ 要 介助群と条件付き自立群間には有意差は認められなかっ た（表2）。

3. 下肢荷重力の両側合計值の比較 非麻痺側と麻痺側の下肢荷重力合計值は, 要介助群 と条件付き自立群間に有意差が認められた $(\mathrm{p}<0.05)$ 。ま た, 条件付き自立群と自立群間で有意差が認められた $(\mathrm{p}<0.05)$ 。要介助群と自立群間にも有意差が認められた $(\mathrm{p}<0.01) （$ 表2）。 


\section{IV. 考 察}

今回, 脳卒中片麻㾝者を対象に端座位での下肢荷重 力を市販体重計によって測定し, 立ち上がり動作能力と の関連について検討した。

非麻摩側下肢荷重力を立ち上がり動作能力別に比較 した結果, 要介助群は条件付き自立群と自立群それぞれ と有意差が認められた。このことから, 非麻痺側下肢荷 重力を測定することで立ち上がり動作の可否を判断で きる可能性が示唆された。しかし, 条件付き自立群と自 立群との間には有意差は認められず, 非麻痺側下肢荷重 力測定のみでは立ち上がり動作時における上肢支持の 必要性の有無は評価できないことが確認された。

麻疩側下肢荷重力を立ち上がり動作能力別に比較し た結果, 自立群は条件付自立群と要介助群それぞれと有 意差が認められた。このことから, 麻瘏側下肢荷重力を 測定することにより立ち上がりが自立できているか, 何 らかの介助を要するかを判断できる可能性が示唆され た。しかし, 条件付き自立群と要介助群との間には有意 差が認められず, 麻盘側下肢荷重力のみの測定ではどの 程度の介助が必要であるのかを判断することはできな い。

非麻疩側下肢および麻痺側下肢別に測定した下肢荷 重力の結果から, 立ち上がりの可否には非麻痺側下肢の 役割が大きく作用していることが考えられる。一方で麻 瘏側下肢は, 上肢での代償が必要か否か, 寸なわち, 立 ち上がり方法を左右する要因となっていることが示唆 された。

非麻瘏側, 麻痺側両側の下肢荷重力合計值を立ち上 がり動作能力別に比較した結果, 要介助群, 条件付き自 立群，自立群それぞれに有意差が認められた。これらの ことから, 非麻㿁側や麻痺側をそれぞれ測定するのでは なく, 両側の下肢荷重力合計值を測定することにより立 ち上がり能力をより詳細に評価できる可能性が示唆さ れた。

本研究で得られた知見から, 座位での下肢荷重力測 定は麻痺側や非麻痺側それぞれを測定・評価するのでは なく, 両側を評価することの重要性が示唆された。ま
た, 脳卒中片麻痺者の立ち上がり動作を反映する簡易下 肢機能評価法として有用であることが示唆された。とく に, 坐位で測定が可能なため, 治療上立ち上がり動作が 許可されていない片麻痺者の立ち上がり動作の予後予 測に使用できる可能性が示唆された。

本研究の対象者は, 通所リハビリテーション施設に 通所する症状が安定した片麻痺者である。今回の結果 が, 急性期の片麻疩者にもあてはまるとは限らない。今 後は, 急性期の片麻痺者での測定を行うこと, さらに は, 回復過程の経過を追った縦断的研究を行うことが課 題である。

\section{引用文献}

1) Brunnstrom S (著)，佐久間楥爾，松村 秩（訳）：片麻痺の 運動療法. 医歯薬出版, 東京, 1974, pp38-62.

2) 上田 敏：目でみるリハビリテーション医学, 第2 版. 東京 大学出版会, 東京, 1999, pp44-47.

3) 脳卒中合同ガイドライン委員会: 脳卒中ガイドライン 2004. 篠原幸人 (編), 協和企画, 東京, 2004, pp173-175.

4) 河合 恒, 西原 賢, 比企静雄: 高齢女性の自由歩行におけ る立脚中の膝屈曲角度, 膝伸展力, 歩行パラメータとの関 係. 理学療法科学, 2005, 20(4): 273-277.

5) Fuchs $\mathrm{S}$, Frisse D, Laass H, et al.: Muscle strength in patients with unicompartmental arthroplasty. Am J Phys Med Rehabil NLM, 2004, 83(8): 650-654.

6) Amiridis IG, Arabatzi F, Violaris P, et al.: Static balance improvement in elderly after dorsiflexors electrostimulation training. Eur J Appl Physiol NLM, 2005, 94(4): 424-433.

7) 三好 圭, 木村貞治, 横川吉晴・他 : 立ち上がり動作後にお ける重心動摇の動摇面積と周波数特性に関する加齢の影響. 身体教育医学研究, 2005, 6(1): 11-19.

8) Morioka S, Miyaoto S, Abe M: Relationship between the center of gravity point in spontaneous standing and the middle point calculated from the center of gravity shifting distance to the non-paralytic and paralytic sides in hemiplegics after stroke. J Phys Ther Sci, 2003, 15(2): 99-103.

9) 村田 伸, 宮崎正光: 障害高齢者の下肢機能評価法一市販体 重計を用いた下肢支持力の測定一. 理学療法科学, 2005, 20(2): 111-114.

10) 村田 伸, 大田尾浩, 有馬幸史・他: 脳卒中片麻疩者におけ る市販体重計を用いた下肢荷重力評価の検討. PTジャーナ ル, 2005, 39: 1101-1105. 